\title{
Indirect 3D printing technology for the fabrication of customised $\beta$-TCP/chitosan scaffold with the shape of rabbit radial head-an in vitro study
}

\author{
Ji-Qi Wang ${ }^{1,2,3}$, Bing-Jie Jiang ${ }^{1,2,3}$, Wei-Jun Guo ${ }^{1}$ and You-Ming Zhao ${ }^{1 *}$
}

\begin{abstract}
Background: With the development of indirect three-dimensional (3D) printing technology, it is possible to customise individual scaffolds to be used in bone transplantation and regeneration. In addition, materials previously limited to the 3D printing (3DP) process due to their own characteristics can also be used well in indirect 3DP. In this study, customised $\beta-T C P / c h i t o s a n$ scaffolds with the shape of rabbit radial head were produced by indirect 3D printing technology.

Methods: Swelling ability, porosity, mechanical characterisation, and degradation rate analysis were performed, and in vitro studies were also implemented to evaluate the proliferation and osteogenic differentiation of bone marrow mesenchymal stem cells (MSCs) on the scaffolds. CCK8 cell proliferation assay kit and alkaline phosphatase (ALP) staining solution were used to study cell proliferation and early ALP content at the scaffold surface. Moreover, the osteogenic differentiation of MSCs on scaffolds was also evaluated through the scanning electron microscopy analysis.

Results: $\beta$-TCP/chitosan scaffold has good performance and degradation rate, and in vitro cell experiments also confirm that the scaffold has adequate cytocompatibility and bioactivity.

Conclusion: This study provides a promising new strategy for the design of customised scaffolds for the repair of complex damaged tissues.
\end{abstract}

Keywords: Three-dimensional printing, Scaffold, Tissue engineering, $\beta$-TCP, Chitosan, Customised

\section{Background}

Radial head fracture is one of the most common elbow fractures in adults and accounts approximately one third of all cases [1]. There are many treatment methods for this type of fracture at present, such as Kirschner wires, hollow screw, plate, and radial head arthroplasty (RHA) [2]. As far as we know, the indication for RHA is the unreconstructable radial head [3-5]. However, previous studies have shown that the functional recovery of some patients after RHA is unsatisfactory. Moreover, there are many complications, including prosthetic loosening,

\footnotetext{
* Correspondence: wmuorthopaedic@sina.com

${ }^{1}$ Department of Orthopaedics, The Second Affiliated Hospital and Yuying Children's Hospital of Wenzhou Medical University, 109\# Xue Yuan Xi Road, Wenzhou 325000, Zhejiang, China

Full list of author information is available at the end of the article
}

wear and tear between the prosthesis and the humerus, and chronic pain caused by the prosthesis, all resulting in increased mechanical stress on the surrounding tissue, inflammation, and even requiring reoperation [6-8].

Clinically, RHA has become increasingly mature. However, there is widespread controversy in the design and application of specific prostheses. Gupta et al. [9] suggested that the present radial head prosthesis does not conform to normal anatomy and that its design is not based on the geometric parameters of the radial head and proximal medulla of the radius. Beredjiklian et al. [10] used MRI to measure the anatomical parameters of the radial head and found that the design parameters of the stem of the radial head prosthesis were larger than the intramedullary diameter of the proximal radius. Many complications might be owed to the failure of

(c) The Author(s). 2019 Open Access This article is distributed under the terms of the Creative Commons Attribution 4.0 International License (http://creativecommons.org/licenses/by/4.0/), which permits unrestricted use, distribution, and reproduction in any medium, provided you give appropriate credit to the original author(s) and the source, provide a link to the Creative Commons license, and indicate if changes were made. The Creative Commons Public Domain Dedication waiver (http://creativecommons.org/publicdomain/zero/1.0/) applies to the data made available in this article, unless otherwise stated. 
the present prosthesis to achieve the normal anatomical shape and size of the radial head and to the poor anatomical matching of the prosthesis to the elbow joint. The shape of the rabbit radial head is complex, and it is difficult to replicate with ready-made prostheses [11]. Rabbit radial head is similar to human radial head, where it is elliptical and the joint disc is eccentric relative to the neck. Previous studies have shown that the contact surface shape of elbow prosthesis is significantly correlated with the corresponding pressure during elbow movement $[12,13]$. Therefore, it is necessary to design an individualised prosthesis for patients.

In recent years, there has been a rapid development of clinical digital assistant technology, providing accurate measurement of the anatomical parameters of the radial head and making it possible for the development of an individual prosthesis based on the anatomical structure of the patient $[14,15]$. Previous studies have made individual joint prostheses through digital assistant technology for application in replacement therapy for hip and knee joints $[16,17]$. However, even if a radial head prosthesis is designed to fit the anatomy of the elbow joint, it may not be able to solve the problems of prosthetic loosening, wear and tear between the prosthesis and the humerus, and longevity of the prosthesis. At this point, a bioactive prosthetic replacement material with high bioactivity and controllable degradability is needed to replace the current materials used in clinical practice to solve the above problems.

Normally, the skeletal system consists mainly of cortical bone and trabecular bone. Cortical bone accounts for about $80 \%$ of the total, with compact structure and low surface area forming a capsule around the bone marrow cavity. In contrast, trabecular bone accounts for about $20 \%$ of the total, consists of a network of interconnected trabeculae, and is separated by a space filled with bone marrow [18]. Normal skeletal system maintains dynamic balance and stability under the action of osteocytes, osteoblasts, and osteoclasts. However, pathological skeleton is prone to osteoporosis and pathological fracture due to some factors such as when the speed of bone absorption is faster than the speed of bone formation, which leads to the decrease of bone trabecula and bone density $[19,20]$. As far as we know, biological scaffolds could guide cell growth and differentiation to the conceived regenerated tissue. Thus, healthy cells can gradually replace natural extracellular matrix scaffolds during biosynthesis [21, 22]. Researchers have been looking for an ideal bone substitute material which can complete mechanical support for bone tissue within a specific time of injury healing. Moreover, it should be non-toxic with no residue to the human body, thereby avoiding the effect of foreign bodies on human tissues [23-27].
Calcium phosphate ceramics are widely used in clinical practice because of their good stability and non-toxic degradation process [28-30]. Among calcium phosphate ceramics, $\beta$-tricalcium phosphate $(\beta$-TCP) could be dissolved under acidic conditions caused by released cells, such as osteoclasts or macrophages Moreover, its degradation rate is ten times higher than hydroxyapatite [31]. However, there are still some deficiencies in the porous $\beta$-TCP scaffolds: First, mechanical properties are insufficient, brittleness is large, and bending resistance is poor; thus, they cannot be used as a repair for the weight-bearing bone defect. Second, there is a lack of inducing activity, and they can only rely on bone conduction to make bone tissue growth. Moreover, osteogenesis is insufficient, and the depth of osteogenesis is limited. Lastly, the degradation rate is difficult to control and does not match the growth rate of new bone [32-34].

Chitosan (CS), as a biopolymer, has attracted much attention due to its biocompatibility and biodegradability, and it has been appreciated in bone tissue engineering [35]. In addition, chitosan used in the production of the scaffolds can interact with negatively charged substances on the surface of bacteria and increase cell wall permeability, thereby playing a bactericidal role [36]. Previous studies have demonstrated that chitosan $/ \beta$-TCP scaffolds have good mechanical and biological properties and can be used as a potential bone repair scaffold [37-39].

Solid freeform fabrication (SFF) is a general term that includes the manufacture of various structures through computer-aided design (CAD) [40]. In addition, other terms are usually used to describe the same principle, such as additive manufacturing (AM), rapid prototyping (RP), and 3D printing (3DP) [40]. SFF, based on medical imaging techniques, can reproduce tissue defects that mimic a particular patient. However, this technology is limited by the range of materials available for processing [41-43]. To overcome this limitation, indirect rapid prototyping (iRP) was proposed, which produces a mould or template for the final scaffold structure using SFF technology [44-46]. The final scaffold parameter requirements are secondary because the mould is a straightforward process of well-established materials [21, 47]. Consequently, due to the thermal mechanical properties not matching the usual temperature and pressure requirements of direct rapid prototyping, some materials are identified as "unprintable", and well-defined three-dimensional (3D) scaffolds can be generated through this approach [48-50]. In addition, iRP allows a direct combination of different materials in a scaffold, including bioactive compounds [42, 50].

In our study, we customised the $\beta-\mathrm{TCP} /$ chitosan scaffold with the shape of New Zealand rabbit radial head through iRP technology, using a negative mould. The final scaffold was produced from a negative replica of a desired radial head shape, then the structure, performance, degradation, 
and ability to induce new bone formation of the scaffold were tested. The purpose of our study is to provide a promising new strategy for the design of customised scaffolds for the repair of complex damaged tissues and a theoretical basis for the feasibility of making a customised, biodegradable, and bioceramic radial head prosthesis that conforms to human anatomy, which can be used in the human body.

\section{Methods}

\section{Materials}

Chitosan (degree of deacetylation $>85 \%$ ), $\beta$-TCP powder ( $\geq 98 \% \beta$-phase basis), paraffin (melting point between 53 and $\left.57^{\circ} \mathrm{C}\right), \mathrm{N}$-hexane, Tris buffer $(\mathrm{pH}=7.4)$, ethanol (EtOH), phosphate-buffered saline (PBS) solution, streptomycin, gentamicin, dexamethasone, ascorbic acid, $\beta$-polyglycerolphosphate disodium, alkaline phosphatase (ALP) staining solution, and glutaraldehyde were purchased from Sigma-Aldrich (St. Louis, MO, USA). Trypsin/EDTA solution, Dulbecco's modified Eagle's medium (DMEM; low-glucose and high-glucose), and foetal bovine serum (FBS) were obtained from Gibco (Grand Island, NY, USA). CCK8 cell proliferation assay kit was purchased from Dojindo (Kumamoto, Japan).

\section{Design and fabrication}

The procedure for mould design and scaffold fabrication is shown in Fig. 1. Briefly, the anatomy of the radial head was separated from CT scans using commercially available software (Mimics, Materialise, Ann Arbor, MI, USA), and a negative replica mould of a desired radial head shape was modelled using computer-aided design
(CAD). The image data defined were rendered by 3D and converted to STL file for 3D printing (3DP). The object was cut into two-dimensional (2D) layers, and each separate slice layer was constructed on a commercially available 3DP machine as previously described $[46,51]$. Generally, the negative replica 3D mould is made of silicon [52].

Chitosan was dissolved in acetic acid $(0.1 \mathrm{M})$ to form a $2 \%(w / v)$ solution. The solution was then mixed through an overhead mixer (IKA T25 Ultra Turrax) for 2 min to obtain a transparent gel. $\beta$-TCP powder $(0.4 \% \mathrm{w} / v)$ was dispersed in ethanol solution for $1 \mathrm{~h}$ to obtain a paste mixture. The paste was then added into chitosan solution and homogenised by magnetic stirrer. Paraffin microspheres (approximately $300 \mu \mathrm{m}$ ) were prepared by dispersion method and used as a porogen in the production of the scaffolds [53, 54]. Then, paraffin microspheres were added to the mixture of $\beta$-TCP and CS solution to form a suspension and stirred overnight [55]. Afterwards, the polymer solution was poured into a negative replica mould with radial head shape and compacted. Next, it was placed at $-20^{\circ} \mathrm{C}$ for $24 \mathrm{~h}$, then freeze-dried for another $24 \mathrm{~h}$. Finally, the scaffolds were taken from the mould, and the porogen was removed using Soxhlet extractor for $24 \mathrm{~h}$, with $\mathrm{N}$-hexane as the refluxing solvent [56]. All the scaffolds were vacuum-dried at $40^{\circ} \mathrm{C}$ for $6 \mathrm{~h}$ and stored at $-20^{\circ} \mathrm{C}$ for further studies.

\section{Swelling ability}

The swelling ability of the scaffold was measured in Tris buffer ( $\mathrm{pH}=7.4$ ) at $37^{\circ} \mathrm{C}$ for up to $24 \mathrm{~h}$ [57]. At each time point, the swollen sample was removed from the
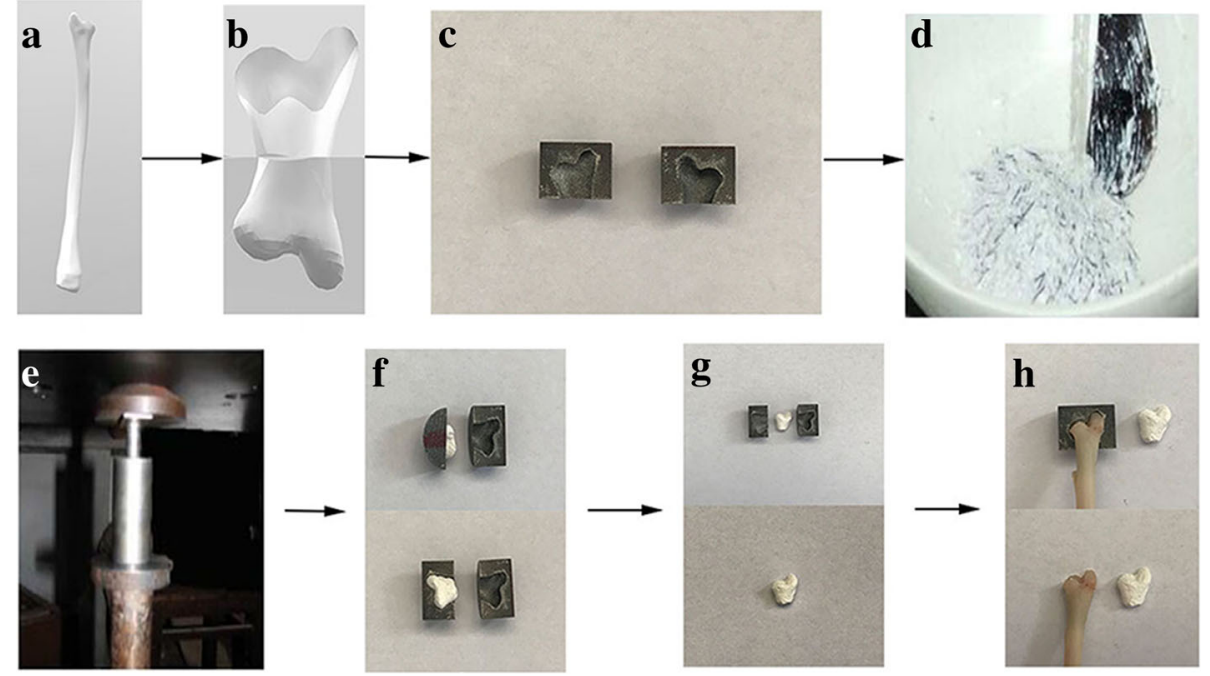

Fig. 1 Scaffold fabrication process by indirect 3DP. a 3D reconstruction of rabbit radial head from CT images. b Creating a negative replica mould using CAD modelling, divided into two parts. c 3D printed the negative replica mould. d Preparation of polymer solutions. e The polymer solution was poured into a negative replica mould with radial head shape and compacted. $\mathbf{f}$, $\mathbf{g}$ Demoulding, removal of paraffin microspheres, and freeze-drying of the scaffold. $\mathbf{h}$ Comparison between rabbit radial head and scaffold 
solution, the excess of Tris buffer was removed with filter paper, and the weight of the sample was measured. Five samples were used for each measurement, and the average value was obtained and used for analysis. The swelling ratio was determined using the following formula:

$$
\text { Swelling ratio }(\%)=\left(W_{\mathrm{s}}-W_{\mathrm{d}}\right) / W_{\mathrm{d}} \times 100
$$

where $W_{\mathrm{s}}$ is the swollen weight of scaffold, and $W_{\mathrm{d}}$ is the initial dry weight of scaffold.

\section{Porosity evaluation}

A liquid displacement method was used to determine the porosity $(P)$ of the scaffold [58]. Ethanol (EtOH) was selected due to its inability to swell or shrink the matrix when permeating through the scaffold. The scaffold was immersed in EtOH for $48 \mathrm{~h}$, and the porosity was determined using the following formula:

$$
P(\%)=\left(W_{2}-W_{1}\right) /\left(d_{\text {ethanol }} \times V_{\text {scaffold }}\right) \times 100 .
$$

where $W_{2}$ and $W_{1}$ represent the wet and dry weight of the scaffold, respectively, while $d_{\text {ethanol }}$ and $V_{\text {scaffold }}$ represent the density of the ethanol and the volume of the scaffold, respectively. Five samples were used for each measurement, and the average value was obtained and used for analysis.

\section{Mechanical properties}

Uniaxial compression assays with $1000 \mathrm{~N}$ of loaded cell and $1 \mathrm{~mm} \mathrm{~min}^{-1}$ crosshead speed conditions were performed to test the compressive strength of the scaffold [59]. Five samples were used, and compressive strength

$(S)$ was determined using the following formula:

$$
S=F_{\max } / A
$$

where $F_{\max }$ and $A$ denote the maximum applied load and the initial contact area of the scaffold, respectively. Average values and standard deviation (SD) were determined.

\section{Determination of degradation rate}

The degradation of scaffold was performed through an adaptation of the method previously used by Kim and collaborators [60], which measured a simulated body fluid (SBF) containing lysozyme. At predetermined intervals, the scaffold was lyophilised and the final dry weight $\left(W_{\mathrm{d}}\right)$ was recorded. Five samples were used for each measurement, and the average value was obtained and used for analysis. The degradation of scaffold was determined using the following formula:

$$
\text { Degradation rate }(\%)=\left(W_{\mathrm{I}}-W_{\mathrm{d}}\right) / W_{\mathrm{I}} \times 100 \text {. }
$$

where $W_{\mathrm{I}}$ and $W_{\mathrm{d}}$ represent the initial and final dry weight of the scaffold, respectively.

\section{Cell culture and seeding}

All animal procedures and protocols were reviewed and approved by the Animal Research Committee of the Wenzhou Medical University. According to the method previously reported by Hokugo et al. [61], bone marrow mesenchymal stem cells (MSCs) were isolated from the iliac bone marrow aspirates of New Zealand white rabbits. Briefly, the density gradient centrifugation method was performed to isolate the MSCs. Then, MSCs were cultured at $37^{\circ} \mathrm{C}$ in a humidified atmosphere containing $5 \%$ $\mathrm{CO}_{2}$. DMEM low-glucose supplemented with foetal bovine serum $(\mathrm{FBS}, 10 \% v / v)$, streptomycin $\left(100 \mu \mathrm{g} \mathrm{ml}^{-1}\right)$, and gentamicin $\left(100 \mu \mathrm{g} \mathrm{ml}^{-1}\right)$ were used as growth medium, which was changed every 3 days. When reaching about $80-90 \%$ confluence, the cells were trypsinised and passaged for further expansion, and the third passage was used in the following experiments. Prior to cell seeding, ultraviolet bactericidal was performed for $30 \mathrm{~min}$, followed by $\mathrm{EtOH}$ immersion for $60 \mathrm{~min}$ for the scaffolds and a wash step with PBS three times [62]. An optical microscope was used to monitor the growth of MSCs.

\section{Cell viability}

Each scaffold was seeded with $50 \mu \mathrm{l}$ of cell suspension at a concentration of $1 \times 10^{6} \mathrm{cells} \mathrm{ml}^{-1}$. After incubation and adhesion for $2 \mathrm{~h}$ at $37^{\circ} \mathrm{C}$, the scaffolds were placed in a 24-well plate and cultured with $1 \mathrm{ml}$ growth media (DMEM low-glucose/10\% FBS). At each time point (24, 48 , and $72 \mathrm{~h}$ ), cell activity in the scaffold was measured by CCK8 cell proliferation assay kit, following the manufacturer's instruction. After washing with PBS, the scaffolds $(n=5)$ were incubated in $180 \mu \mathrm{l}$ of fresh medium with $20 \mu \mathrm{l}$ of CCK8 assay solution in 24-well plates for $1 \mathrm{~h}$. A Multiskan Spectrum (Thermo Fisher Scientific, USA) at a wavelength of $450 \mathrm{~nm}$ was used to measure the optical density of each well.

\section{Alkaline phosphatase staining and scanning electron microscopy analysis for osteogenic differentiation}

Each scaffold was seeded with $50 \mu \mathrm{l}$ of cell suspension at a concentration of $1 \times 10^{6}$ cells ml ${ }^{-1}$. After incubation and adhesion for $2 \mathrm{~h}$ at $37^{\circ} \mathrm{C}$, the scaffolds were placed in a 24-well plate and cultured with $1 \mathrm{ml}$ growth media (DMEM low-glucose/10\% FBS) for $24 \mathrm{~h}$ then cultured in osteogenic medium, which was changed every 2 days. The osteogenic medium was DMEM high-glucose supplemented with $5 \% \mathrm{FBS}, 0.1 \mu \mathrm{M}$ dexamethasone, $50 \mu \mathrm{M}$ ascorbic acid, $10 \mathrm{mM} \beta$-polyglycerolphosphate disodium, $100 \mu \mathrm{g} \mathrm{ml}^{-1}$ streptomycin, and $100 \mu \mathrm{g} \mathrm{ml}^{-1}$ gentamicin. After incubation for 7 days, the osteogenic differentiation scaffold was washed with serum-free DMEM high-glucose for $8 \mathrm{~h}$ to remove serum components, then with PBS three times. Next, the scaffolds were immersed in stationary liquid for $2 \mathrm{~h}$. Afterwards, the immobilised 
scaffolds were immersed in ALP staining kit for $2 \mathrm{~h}$ according to the manufacturer's instruction for.

For scanning electron microscopy (SEM) analysis, at each time point (incubation for 14 and 28 days), the post-seed scaffolds were washed with PBS and fixed overnight with $2.5 \%(v / v)$ glutaraldehyde. Then, the scaffolds were washed three times in PBS and dehydrated in grading EtOH solutions (50, 60, 70, 80, 90, and 99.9\%). Liquid nitrogen was used to freeze the scaffolds, which were freeze-dried for $3 \mathrm{~h}$ then mounted onto aluminium stubs with double adhesive tape and sputter-coated with gold using a Quorum Q150R ES sputter coater. SEM images were obtained with an acceleration voltage of 20 $\mathrm{kV}$ at variable magnifications using a Hitachi S-3400 N Scanning Electron Microscope [63].

\section{Results}

Figure 1 shows a fabricated mould with an external shape matching the radial head of New Zealand rabbit through 3D printing technology. In this study, the swelling ability of the scaffold in PBS is shown in Fig. 2. The rate of increase is highest after $30 \mathrm{~min}$, and then the change tends to stabilise. We used the liquid displacement method to evaluate the porosity of scaffolds. The porosity of all scaffolds was higher than $75 \%$, and the mean porosity was $78.98 \pm 2.42 \%$. Then, we used a uniaxial compression test to evaluate the compressive strength of the scaffolds. The mean compressive strength was $1.73 \pm 0.09$ MPa. Moreover, we found that the mean mass loss of scaffold in the first month was $15.70 \pm 1.24 \%$.

Cell viability on scaffold was characterised using a CCK8 cell proliferation assay kit (Fig. 3). ALP staining suggests that MSCs could induce osteogenic differentiation on the scaffold within osteogenic differentiation medium at an early stage (Fig. 4). Finally, the surface topographical features of cells on scaffold were imaged by SEM (Fig. 5).

\section{Discussion}

As far as we know, many similar studies have used different methods to prepare polymer/bioceramic composite materials [64, 65]. For example, Heydary et al. [66] prepared polyvinyl alcohol (PVA)/Iranian gum tragacanth (IGT) nanocomposite fibre by electrospinning (ELS) technique. Furthermore, Khandan et al. [67] synthesised magnetite nanoparticles by co-precipitation method and a novel bredigitemagnetite nanocomposite by mechanical grinding and subsequent sintering process combined with bredigite powders. In our study, $\beta$-TCP/ chitosan scaffold is a type of composite bioceramics that acts as osteoconduction and structural support. Complex three-dimensional anatomical scaffolds were fabricated by indirect 3DP technology combined with imaging technology, and CT data were used to design the anatomical radial head. In tissue engineering scaffolds, porogen was added to enhance the transport of oxygen and nutrients to maintain cell viability and promote vascular endogenous growth in the graft $[68,69]$. Murphy et al. [70] studied the effect of $85-325-\mu \mathrm{m}$ pore size on cell activity and found that the number of cells at the maximum pore size were always the highest, prompting them to define $325 \mu \mathrm{m}$ as the optimal pore size for cell proliferation. Moreover, it has been reported that pore size greater than $300 \mu \mathrm{m}$ was essential for bone ingrowth and scaffold vascularisation [71]. Scaffolds were produced by pouring the polymer solution into the printed mould with radial head shape and compacted.

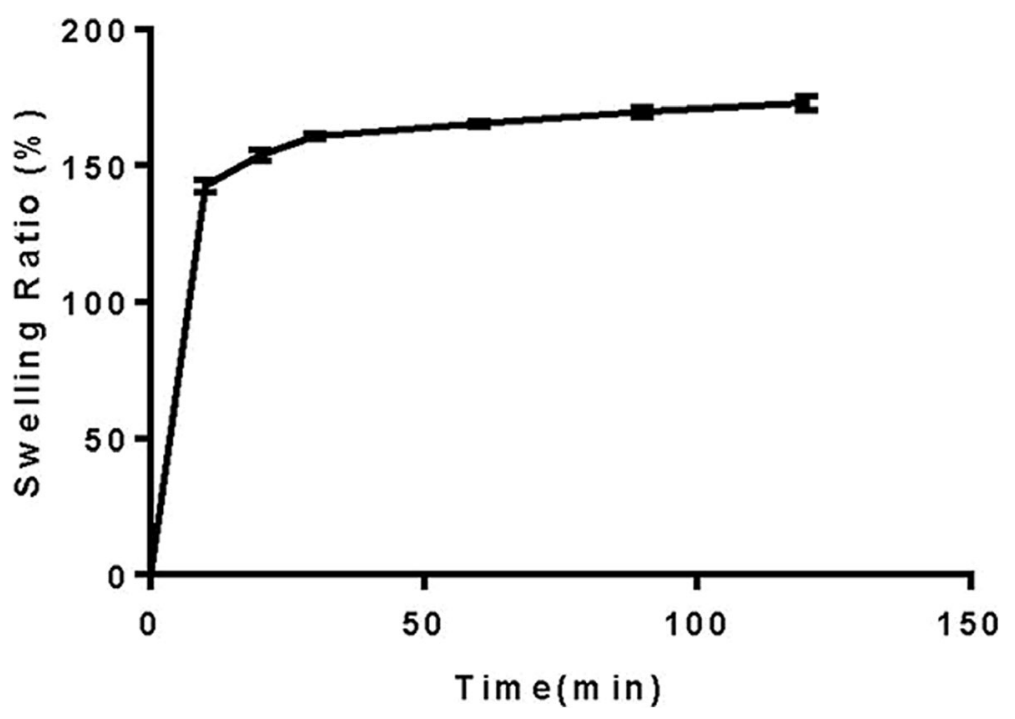

Fig. 2 Swelling profile of the scaffold produced 


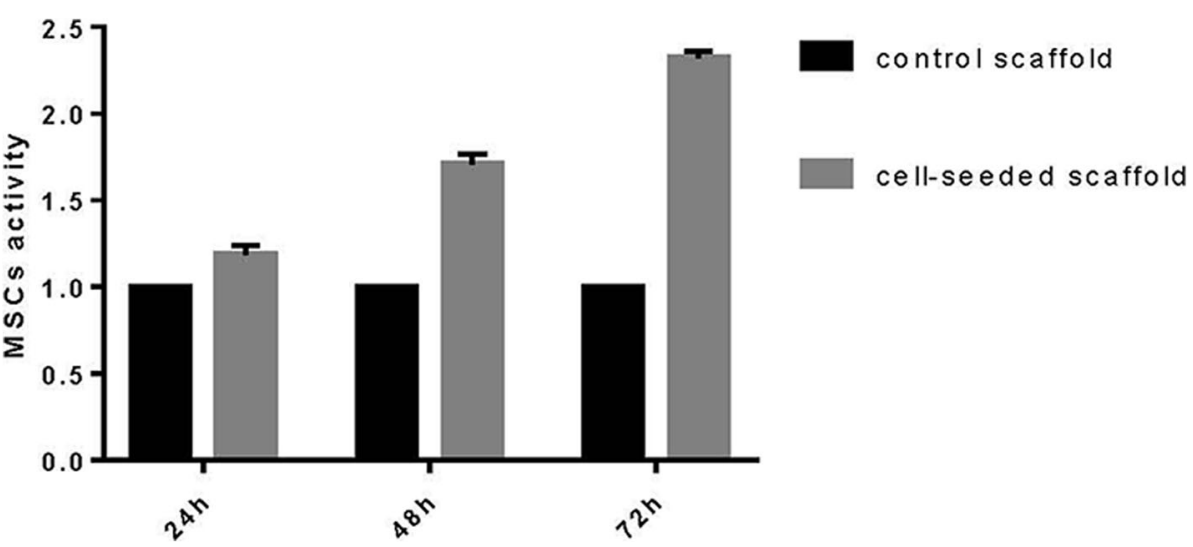

Fig. 3 Evaluation of cell viability in the presence of the scaffolds. Cell viability was evaluated after 24, 48, and $72 \mathrm{~h}$ using a CCK 8 assay. Scaffolds without cell seeding were used as a control group

\section{In vitro performance testing}

Fluid absorption capacity is necessary for scaffolds in tissue engineering [72], and satisfactory swelling ability not only promotes cell attachment but also cell internalisation, which is the basis for improving tissue regeneration process. In addition, high swelling ability can also promote the diffusion of nutrients and wastes along the structure [73]. However, excessive swelling ability leads to loss of mechanical integrity and compressive stress of surrounding tissues [74]. In our study, the rate of increase is highest after $30 \mathrm{~min}$, then the change tends to stabilise, which means scaffold has a satisfactory fluid absorption capacity. The porous structure of scaffolds is of great significance for cell proliferation, differentiation, and function [75]. The porosity of all scaffolds was greater than $75 \%$, and the mean porosity was $78.98 \pm$ $2.42 \%$. In fact, interconnected pores promote the

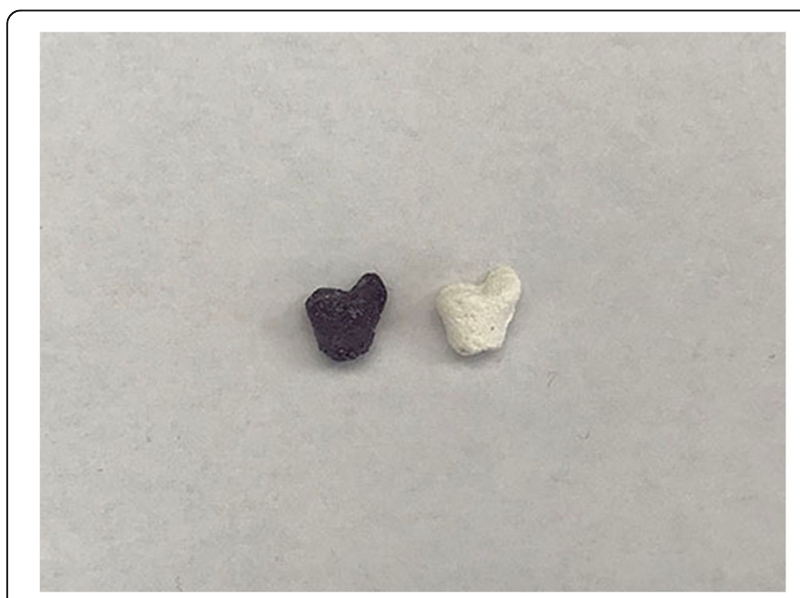

Fig. 4 Alkaline phosphatase (ALP) staining. The existence of ALP was tested in early osteogenic differentiation of MSCs in the presence of the scaffolds after 7 days using an ALP staining solution. Left: alkaline phosphatase stained after 7 days of incubation with MSCs. Right: control after 7 days in the same media without MSCs and stained formation of vascular networks in scaffolds and provide channels for free diffusion of ions, nutrients, and cells. The diffusion of calcium ion and phosphate anion in the scaffold can produce a layered material similar to hydroxyapatite (HA), which stimulates the activity of osteoblasts [59]. Additionally, the HA-like layer can also increase bone conduction and osseointegration, further improving bone mineralisation [76]. As far as we know, the characterisation of compressive strength is very important for the design and production of bone tissue engineering scaffolds [77, 78]. The mean compressive strength was $1.73 \pm 0.09 \mathrm{MPa}$. Our results show that the mechanical strength of the produced scaffold is lower than that of trabecular bone (2-20 MPa) [79]. Actually, the scaffold similar to this kind of production only needs to play a template in the first stage of bone regeneration. When the scaffold begins to be biodegraded, it will be replaced by the new bone matrix, which is compatible with the formation of the new bone tissue [77, 80]. These characteristics enable it to provide temporary support in the mineralisation stage, accelerate the regeneration process, and improve the mechanical capability of the target position [81]. Our preliminary data are consistent with the results of Siddiqui et al. [82], and we found the mean mass loss of scaffold in the first month was $15.70 \pm 1.24 \%$, indicating that the scaffold has good degradation ability. When the degradation rate of the scaffold matches the osteogenesis rate of the new bone, the scaffold can provide adequate temporary support.

\section{Cell viability and osteogenic differentiation}

Cell viability on scaffold was characterised through a CCK8 cell proliferation assay kit. The results demonstrate that with the increase of culture time, MSCs can proliferate on scaffold satisfactorily. Then, we tested the ALP activity, an early indicator of MSCs induced to osteoblasts, through an ALP staining solution. The results 


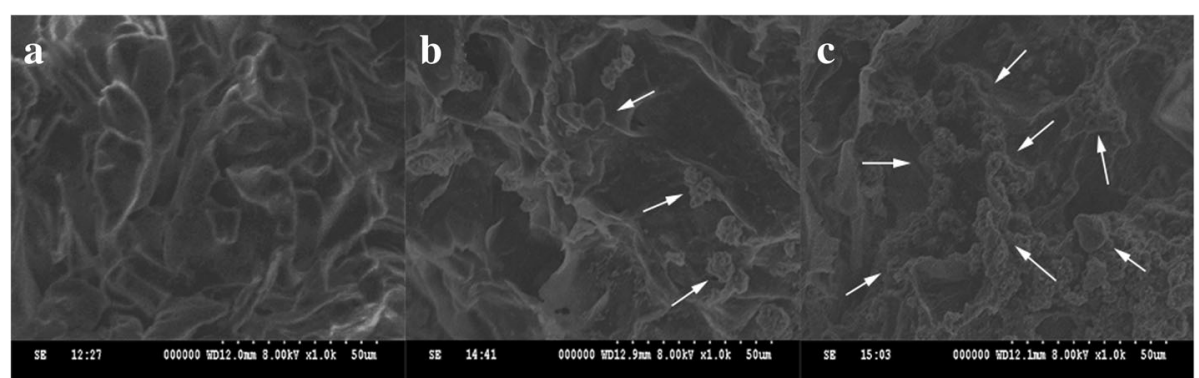

Fig. 5 The surface topographical features of cells on scaffold imaged by scanning electron microscopy (SEM). a SEM image of $\beta$-TCP/chitosan scaffold. b After 14 days of incubation in osteogenic medium, the cells contacted to each other and spread on the surface of the scaffold. Moreover, spherical and polygonal adhesion on the surface and around the pores of the scaffold were observed (arrow). c On day 28, large patches and crumby structure of adhesions were seen on the surface and around the pores of the scaffolds, which was increased significantly compared to 14 days prior (arrow)

suggest that MSCs could induce osteogenic differentiation on the scaffold within osteogenic differentiation medium at an early stage. Finally, the surface topographical features of cells on scaffold were imaged by scanning electron microscopy (SEM). After 14 days of incubation in osteogenic medium, the cells contacted to each other and spread on the surface of the scaffold. Moreover, spherical and polygonal adhesion on the surface and around the pores of the scaffold were observed. On day 28 , large patches and crumby structure of adhesions were noted on the surface and around the pores of the scaffolds, which was increased significantly compared to 14 days prior. The images showed that the proliferation and osteogenic differentiation of the cells increased with culture time.

\section{Conclusions}

In this study, we demonstrated an indirect 3DP technology to create a customised scaffold with anatomic radial head shape. Briefly, $\beta$-TCP and chitosan polymer solution were mixed with paraffin microspheres porogens and poured into a negative replica mould, which was produced by indirect 3DP technology. Subsequently, a leaching technique was used to fabricate the final porous scaffold. We found that the scaffold has good performance and degradation rate. Moreover, in vitro cell experiments also confirm that the scaffold has adequate cytocompatibility and bioactivity. Further studies are required to determine whether this scaffold supports tissue regeneration in vivo. This study provides a promising new strategy for the design of customised scaffolds for the repair of complex damaged tissues.

\section{Abbreviations}

3DP: 3D printing; ALP: Alkaline phosphatase; AM: Additive manufacturing; CAD: Computer-aided design; CS: Chitosan; DMEM: Dulbecco's modified Eagle's medium; FBS: Foetal bovine serum; HA: Hydroxyapatite; iRP: Indirect rapid prototyping; MSCs: Mesenchymal stem cells; PBS: Phosphate-buffered saline solution; RHA: Radial head arthroplasty; RP: Rapid prototyping;
SBF: Simulated body fluid; SEM: Scanning electron microscopy; SFF: Solid freeform fabrication; $\beta$-TCP: $\beta$-tricalcium phosphate

\section{Acknowledgements}

We thank the guidance of the staff of the Scanning Electron Microscope Laboratory of Wenzhou Medical University.

Funding

This study was funded by Natural Science Foundation of Zhejiang Province (LY15H060009).

Availability of data and materials

The datasets analyzed in the study are available from the corresponding author on reasonable request.

\section{Authors' contributions}

YMZ and WJG designed the study and revised the manuscript. JQW and BJJ ran the experiments and participated in data analysis. JQW drafted the manuscript. All authors commented on the manuscript and gave final approval for publication.

\section{Ethics approval and consent to participate}

The protocol for animal care and use conformed to the guidelines set forth by the Chinese National Institutes of Health and was approved by the Animal Care and Use Committee of Wenzhou Medical University.

Consent for publication

Not applicable.

\section{Competing interests}

The authors declare that they have no competing interests.

\section{Publisher's Note}

Springer Nature remains neutral with regard to jurisdictional claims in published maps and institutional affiliations.

\section{Author details}

'Department of Orthopaedics, The Second Affiliated Hospital and Yuying Children's Hospital of Wenzhou Medical University, 109\# Xue Yuan Xi Road, Wenzhou 325000, Zhejiang, China. ${ }^{2}$ Key Laboratory of Orthopedics of Zhejiang Province, Wenzhou 325000, Zhejiang, China. ${ }^{3}$ The Second School of Medicine, Wenzhou Medical University, Wenzhou 325000, Zhejiang, China.

Received: 31 December 2018 Accepted: 27 March 2019

Published online: 11 April 2019

\section{References}

1. Kaas $L$, van Riet RP, Vroemen JP, Eygendaal D. The epidemiology of radial head fractures. J Shoulder Elb Surg. 2010;19(4):520-3. 
2. Ruchelsman DE, Christoforou D, Jupiter JB. Fractures of the radial head and neck. J Bone Joint Surg Am. 2013;95(5):469-78.

3. Johnson JA, Beingessner DM, Gordon KD, Dunning CE, Stacpoole RA, King GJ. Kinematics and stability of the fractured and implant-reconstructed radial head. J Shoulder Elbow Surg. 2005;14(1 Suppl S):195s-201s.

4. Pike JM, Grewal R, Athwal GS, Faber KJ, King GJ. Open reduction and internal fixation of radial head fractures: do outcomes differ between simple and complex injuries? Clin Orthop Relat Res. 2014;472(7):2120-7.

5. Ruan HJ, Fan CY, Liu JJ, Zeng BF. A comparative study of internal fixation and prosthesis replacement for radial head fractures of Mason type III. Int Orthop. 2009;33(1):249-53

6. Tarallo L, Mugnai R, Rocchi M, Capra F, Catani F. Mason type III radial head fractures treated by anatomic radial head arthroplasty: is this a safe treatment option? Orthop Traumatol Surg Res. 2017;103(2):183-9.

7. Moro JK, Werier J, MacDermid JC, Patterson SD, King GJ. Arthroplasty with a metal radial head for unreconstructible fractures of the radial head. J Bone Joint Surg Am Vol. 2001;83-a(8):1201-11.

8. Harrington IJ, Sekyi-Otu A, Barrington TW, Evans DC, Tuli V. The functional outcome with metallic radial head implants in the treatment of unstable elbow fractures: a long-term review. J Trauma. 2001;50(1):46-52.

9. Gupta GG, Lucas G, Hahn DL. Biomechanical and computer analysis of radial head prostheses. J Shoulder Elb Surg. 1997;6(1):37-48.

10. Beredjiklian PK, Nalbantoglu U, Potter HG, Hotchkiss RN. Prosthetic radial head components and proximal radial morphology: a mismatch. J Shoulder Elb Surg. 1999;8(5):471-5.

11. Bachman DR, Thaveepunsan S, Park S, Fitzsimmons JS, An KN, O'Driscoll SW. The effect of prosthetic radial head geometry on the distribution and magnitude of radiocapitellar joint contact pressures. J Hand Surg. 2015;40(2):281-8.

12. Shannon HL, Deluce SR, Giles JW, Johnson JA, King GJ. The effect of radial head implant shape on radiocapitellar kinematics during in vitro forearm rotation. J Shoulder Elb Surg. 2015;24(2):258-64.

13. Shannon HL, Deluce SR, Lalone EA, Willing R, King GJ, Johnson JA. Effect of radial head implant shape on joint contact area and location during static loading. J Hand Surg. 2015;40(4):716-22.

14. Ten Berg PW, Dobbe JG, van Wolfswinkel G, Strackee SD, Streekstra GJ. Validation of the contralateral side as reference for selecting radial head implant sizes. Surg Radiol Anat. 2016;38(7):801-7.

15. Guitton TG, Ring D. Interobserver reliability of radial head fracture classification: two-dimensional compared with three-dimensional CT. J Bone Joint Surg Am. 2011;93(21):2015-21.

16. Zhang YZ, Lu S, Zhang HQ, Jin ZM, Zhao JM, Huang J, et al. Alignment of the lower extremity mechanical axis by computer-aided design and application in total knee arthroplasty. Int J Comput Assist Radiol Surg. 2016; 11(10):1881-90.

17. Zheng $P$, Yao Q, Xu P, Wang L. Application of computer-aided design and 3D-printed navigation template in Locking Compression Pediatric Hip Plate (TauMu) placement for pediatric hip disease. Int J Comput Assist Radiol Surg. 2017;12(5):865-71.

18. Clarke B. Normal bone anatomy and physiology. Clin J Am Soc Nephrol. 2008;3(Suppl 3):S131-9.

19. Singh S, Bray TJP, Hall-Craggs MA. Quantifying bone structure, microarchitecture, and pathophysiology with MRI. Clin Radiol. 2018;73(3):221-30.

20. Bonewald LF. The amazing osteocyte. J Bone Miner Res. 2011;26(2):229-38.

21. Chia HN, Wu BM. Recent advances in 3D printing of biomaterials. J Biol Eng. 2015:9:4.

22. Liu CZ, Xia ZD, Han ZW, Hulley PA, Triffitt JT, Czernuszka JT. Novel 3D collagen scaffolds fabricated by indirect printing technique for tissue engineering. J Biomed Mater Res B Appl Biomater. 2008;85(2):519-28.

23. Gupta P, Adhikary M, Moses JC, Kumar M, Bhardwaj N, Mandal BB. Biomimetic, osteoconductive non-mulberry silk fiber reinforced tricomposite scaffolds for bone tissue engineering. ACS Appl Mater Interfaces. 2016;8(45): 30797-810.

24. Denry I, Goudouri OM, Fredericks DC, Akkouch A, Acevedo MR, Holloway JA. Strontium-releasing fluorapatite glass-ceramic scaffolds: Structural characterization and in vivo performance. Acta Biomaterialia. 2018;75:463-71

25. Liu A, Sun M, Yang $X, M a C$, Liu Y, Yang X, et al. Three-dimensional printing akermanite porous scaffolds for load-bearing bone defect repair: An investigation of osteogenic capability and mechanical evolution. J Biomater Appl. 2016;31(5):650-60.

26. Oryan A, Alidadi S, Bigham-Sadegh A, Moshiri A. Comparative study on the role of gelatin, chitosan and their combination as tissue engineered scaffolds on healing and regeneration of critical sized bone defects: an in vivo study. J Mater Sci Mater Med. 2016;27(10):155.

27. Yazdimamaghani $M$, Razavi M, Vashaee D, Moharamzadeh $K$, Boccaccini AR, Tayebi L. Porous magnesium-based scaffolds for tissue engineering. Mater Sci Eng C Mater Biol Appl. 2017;71:1253-66.

28. Marcacci M, Kon E, Zaffagnini S, Giardino R, Rocca M, Corsi A, et al. Reconstruction of extensive long-bone defects in sheep using porous hydroxyapatite sponges. Calcif Tissue Int. 1999;64(1):83-90.

29. Quarto R, Mastrogiacomo M, Cancedda R, Kutepov SM, Mukhachev V, Lavroukov A, et al. Repair of large bone defects with the use of autologous bone marrow stromal cells. N Engl J Med. 2001;344(5):385-6.

30. Rueger JM. Bone substitution materials. Current status and prospects. Der Orthopade. 1998;27(2):72-9.

31. Wiesmann HP, Joos U, Meyer U. Biological and biophysical principles in extracorporal bone tissue engineering. Part II. Int J Oral Maxillofac Surg. 2004;33(6):523-30

32. Ohura K, Bohner M, Hardouin P, Lemaitre J, Pasquier G, Flautre B. Resorption of, and bone formation from, new beta-tricalcium phosphate-monocalcium phosphate cements: an in vivo study. J Biomed Mater Res. 1996;30(2):193200.

33. Ohsawa $\mathrm{K}, \mathrm{Neo} \mathrm{M}$, Matsuoka $\mathrm{H}$, Akiyama $\mathrm{H}$, Ito $\mathrm{H}$, Kohno $\mathrm{H}$, et al. The expression of bone matrix protein mRNAs around beta-TCP particles implanted into bone. J Biomed Mater Res. 2000;52(3):460-6.

34. Lu J, Blary MC, Vavasseur S, Descamps M, Anselme K, Hardouin P. Relationship between bioceramics sintering and micro-particles-induced cellular damages. J Mater Sci Mater Med. 2004;15(4):361-5.

35. Bernkop-Schnurch A. Chitosan and its derivatives: potential excipients for peroral peptide delivery systems. Int J Pharm. 2000;194(1):1-13.

36. Miguel SP, Ribeiro MP, Brancal H, Coutinho P, Correia IJ. Thermoresponsive chitosan-agarose hydrogel for skin regeneration. Carbohydr Polym. 2014; 111:366-73.

37. Detsch R, Mayr H, Ziegler G. Formation of osteoclast-like cells on HA and TCP ceramics. Acta Biomater. 2008;4(1):139-48.

38. Yin Y, Ye F, Cui J, Zhang F, Li X, Yao K. Preparation and characterization of macroporous chitosan-gelatin/beta-tricalcium phosphate composite scaffolds for bone tissue engineering. J Biomed Mater Res A. 2003;67(3): 844-55.

39. Zhao F, Grayson WL, Ma T, Bunnell B, Lu WW. Effects of hydroxyapatite in 3D chitosan-gelatin polymer network on human mesenchymal stem cell construct development. Biomaterials. 2006;27(9):1859-67.

40. Billiet T, Vandenhaute M, Schelfhout J, Van Vlierberghe S, Dubruel P. A review of trends and limitations in hydrogel-rapid prototyping for tissue engineering. Biomaterials. 2012;33(26):6020-41.

41. Mondrinos MJ, Dembzynski R, Lu L, Byrapogu VK, Wootton DM, Lelkes PI, et al. Porogen-based solid freeform fabrication of polycaprolactone-calcium phosphate scaffolds for tissue engineering. Biomaterials. 2006;27(25):4399-408.

42. Taboas JM, Maddox RD, Krebsbach PH, Hollister SJ. Indirect solid free form fabrication of local and global porous, biomimetic and composite 3D polymer-ceramic scaffolds. Biomaterials. 2003;24(1):181-94.

43. Lu L, Zhang Q, Wootton D, Chiou R, Li D, Lu B, et al. Biocompatibility and biodegradation studies of PCL/beta-TCP bone tissue scaffold fabricated by structural porogen method. J Mater Sci Mater Med. 2012;23(9):2217-26.

44. Schumacher M, Deisinger U, Detsch R, Ziegler G. Indirect rapid prototyping of biphasic calcium phosphate scaffolds as bone substitutes: influence of phase composition, macroporosity and pore geometry on mechanical properties. J Mater Sci Mater Med. 2010;21(12):3119-27.

45. Schumacher M, Uhl F, Detsch R, Deisinger U, Ziegler G. Static and dynamic cultivation of bone marrow stromal cells on biphasic calcium phosphate scaffolds derived from an indirect rapid prototyping technique. J Mater Sci Mater Med. 2010;21(11):3039-48.

46. Lee $\mathrm{M}, \mathrm{Wu}$ BM, Dunn JC. Effect of scaffold architecture and pore size on smooth muscle cell growth. J Biomed Mater Res A. 2008;87(4):1010-6.

47. Kang HW, Cho DW. Development of an indirect stereolithography technology for scaffold fabrication with a wide range of biomaterial selectivity. Tissue Eng Part C Methods. 2012;18(9):719-29.

48. Chu TM, Orton DG, Hollister SJ, Feinberg SE, Halloran JW. Mechanical and in vivo performance of hydroxyapatite implants with controlled architectures. Biomaterials. 2002;23(5):1283-93.

49. Lee JY, Choi B, Wu B, Lee M. Customized biomimetic scaffolds created by indirect three-dimensional printing for tissue engineering. Biofabrication. 2013;5(4):045003. 
50. Li LH, Kommareddy KP, Pilz C, Zhou CR, Fratzl P, Manjubala I. In vitro bioactivity of bioresorbable porous polymeric scaffolds incorporating hydroxyapatite microspheres. Acta Biomater. 2010;6(7):2525-31.

51. Lee M, Dunn JC, Wu BM. Scaffold fabrication by indirect three-dimensional printing. Biomaterials. 2005;26(20):4281-9.

52. Houben A, Van Hoorick J, Van Erps J, Thienpont H, Van Vlierberghe S, Dubruel $P$. Indirect rapid prototyping: opening up unprecedented opportunities in scaffold design and applications. Ann Biomed Eng. 2017; 45(1):58-83

53. Draghi L, Resta S, Pirozzolo MG, Tanzi MC. Microspheres leaching for scaffold porosity control. J Mater Sci Mater Med. 2005;16(12):1093-7.

54. Zhang L, Ke X, Lin L, Xiao J, Yang X, Wang J, et al. Systematic evaluation of the osteogenic capacity of low-melting bioactive glass-reinforced $45 \mathrm{S5}$ Bioglass porous scaffolds in rabbit femoral defects. Biomed Mater. 2017; 12(3):035010

55. Bi L, Cao Z, Hu Y, Song Y, Yu L, Yang B, et al. Effects of different crosslinking conditions on the properties of genipin-cross-linked chitosan/ collagen scaffolds for cartilage tissue engineering. J Mater Sci Mater Med. 2011;22(1):51-62.

56. Ruixin L, Dong L, Bin Z, Hao L, Xue L, Caihong S, et al. A mechanical evaluation of micro-HA/CS composite scaffolds with interconnected spherical macropores. Biomed Eng Online. 2016;15:12.

57. Coimbra P, Alves P, Valente TAM, Santos R, Correia IJ, Ferreira P. Sodium hyaluronate/chitosan polyelectrolyte complex scaffolds for dental pulp regeneration: synthesis and characterization. Int J Biol Macromol. 2011;49(4): 573-9.

58. Jiang L, Li Y, Xiong C, Su S, Ding H. Preparation and properties of Bamboo Fiber/Nano-hydroxyapatite/Poly(lactic-co-glycolic) composite scaffold for bone tissue engineering. ACS Appl Mater Interfaces. 2017;9(5):4890-7.

59. Torres AL, Gaspar VM, Serra IR, Diogo GS, Fradique R, Silva AP, et al. Bioactive polymeric-ceramic hybrid 3D scaffold for application in bone tissue regeneration. Mater Sci Eng C Mater Biol Appl. 2013;33(7):4460-9.

60. Kim HM, Miyaji F, Kokubo T, Nakamura T. Preparation of bioactive Ti and its alloys via simple chemical surface treatment. J Biomed Mater Res. 1996; 32(3):409-17.

61. Hokugo A, Sorice S, Yalom A, Lee JC, Li A, Zuk P, et al. In vitro study of a novel oxysterol for osteogenic differentiation on rabbit bone marrow stromal cells. Plast Reconstr Surg. 2013;132(1):70e-80e.

62. Chen VJ, Smith LA, Ma PX. Bone regeneration on computer-designed nanofibrous scaffolds. Biomaterials. 2006:27(21):3973-9.

63. Ribeiro MP, Morgado PI, Miguel SP, Coutinho P, Correia IJ. Dextran-based hydrogel containing chitosan microparticles loaded with growth factors to be used in wound healing. Mater Sci Eng C. 2013;33(5):2958-66.

64. Abdellahi M, Najafinezhad A, Ghayour H, Saber-Samandari S, Khandan A. Preparing diopside nanoparticle scaffolds via space holder method: simulation of the compressive strength and porosity. J Mech Behav Biomed Mater. 2017;72:171-81.

65. Khandan A, Ozada N, Saber-Samandari S, Ghadiri NM. On the mechanical and biological properties of bredigite-magnetite (Ca7MgSi4O16-Fe3O4) nanocomposite scaffolds. Ceram Int. 2018;44(3):3141-8.

66. Heydary HA, Karamian E, Poorazizi E, Heydaripour J, Khandan A. Electrospun of polymer/bioceramic nanocomposite as a new soft tissue for biomedical applications. J Asian Ceramic Soc. 2018;3(4):417-25.

67. Khandan A, Ozada N. Bredigite-magnetite (Ca7MgSi4O16-Fe3O4) nanoparticles: a study on their magnetic properties. J Alloys Compd. 2017; 726:729-36.

68. Nazhat SN, Neel EA, Kidane A, Ahmed I, Hope C, Kershaw M, et al. Controlled microchannelling in dense collagen scaffolds by soluble phosphate glass fibers. Biomacromolecules. 2007;8(2):543-51.

69. Radisic M, Park H, Gerecht S, Cannizzaro C, Langer R, Vunjak-Novakovic G. Biomimetic approach to cardiac tissue engineering. Philos Trans R Soc Lond Ser B Biol Sci. 2007;362(1484):1357-68.

70. Murphy CM, Haugh MG, O'Brien FJ. The effect of mean pore size on cell attachment, proliferation and migration in collagen-glycosaminoglycan scaffolds for bone tissue engineering. Biomaterials. 2010;31(3):461-6.

71. Karageorgiou V, Kaplan D. Porosity of 3D biomaterial scaffolds and osteogenesis. Biomaterials. 2005;26(27):5474-91.

72. Peng Z, Peng Z, Shen Y. Fabrication and properties of gelatin/chitosan composite hydrogel. Polym-Plast Technol Eng. 2011;50(11):1160-4.
73. Boccardi E, Belova IV, Murch GE, Boccaccini AR, Fiedler T. Oxygen diffusion in marine-derived tissue engineering scaffolds. J Mater Sci Mater Med. 2015; 26(6):200.

74. Li Z, Ramay HR, Hauch KD, Xiao D, Zhang M. Chitosan-alginate hybrid scaffolds for bone tissue engineering. Biomaterials. 2005;26(18):3919-28.

75. Ma L, Gao C, Mao Z, Zhou J, Shen J, Hu X, et al. Collagen/chitosan porous scaffolds with improved biostability for skin tissue engineering. Biomaterials. 2003;24(26):4833-41.

76. Hench LL. Bioactive materials: the potential for tissue regeneration. J Biomed Mater Res. 1998;41(4):511-8.

77. Yuji Y, Fen Y, Junfeng C, Fujiang Z, Xiulan L, Kangde Y. Preparation and characterization of macroporous chitosan-gelatin/ $\beta$-tricalcium phosphate composite scaffolds for bone tissue engineering. J Biomed Mater Res A. 2003;67A(3):844-55.

78. Panzavolta S, Fini M, Nicoletti A, Bracci B, Rubini K, Giardino R, et al. Porous composite scaffolds based on gelatin and partially hydrolyzed a-tricalcium phosphate. Acta Biomater. 2009;5(2):636-43.

79. Bose S, Roy M, Bandyopadhyay A. Recent advances in bone tissue engineering scaffolds. Trends Biotechnol. 2012;30(10):546-54.

80. Miranda SCCC, Silva GAB, Hell RCR, Martins MD, Alves JB, Goes AM. Threedimensional culture of rat BMMSCs in a porous chitosan-gelatin scaffold: a promising association for bone tissue engineering in oral reconstruction. Arch Oral Biol. 2011;56(1):1-15.

81. Bi L, Cheng W, Fan H, Pei G. Reconstruction of goat tibial defects using an injectable tricalcium phosphate/chitosan in combination with autologous platelet-rich plasma. Biomaterials. 2010;31(12):3201-11.

82. Siddiqui N, Pramanik K, Jabbari E. Osteogenic differentiation of human mesenchymal stem cells in freeze-gelled chitosan/nano beta-tricalcium phosphate porous scaffolds crosslinked with genipin. Mater Sci Eng C Mater Biol Appl. 2015;54:76-83.

Ready to submit your research? Choose BMC and benefit from:

- fast, convenient online submission

- thorough peer review by experienced researchers in your field

- rapid publication on acceptance

- support for research data, including large and complex data types

- gold Open Access which fosters wider collaboration and increased citations

- maximum visibility for your research: over $100 \mathrm{M}$ website views per year

At BMC, research is always in progress.

Learn more biomedcentral.com/submissions 